\title{
The Influence of Various Carbohydrates on the Feeding Pattern of Rats Fed Zinc-Deficient Diets
}

\author{
Hirokazu KuBota, Tomoko OHYAma, Yoko HorIKAWA, Koichi MATSUdA, \\ Shigeko FujIMOTO-SAKATA and Nanaya TAMAKI* \\ Faculty of Nutrition and High Technology Research Center, Kobe Gakuin University, \\ Nishi-ku, Kobe 251-2180, Japan \\ (Received October 26, 2002)
}

\begin{abstract}
Summary When dextrin, maltose, sucrose, glucose, and fructose were used as a source of carbohydrate in a diet, the food intake of rats fed either a Zn-adequate or Zn-deficient diet was evaluated daily over $28 \mathrm{~d}$. The average food intake of all groups of rats fed the Zn-deficient diet was significantly lower than that of the corresponding groups of Zn-adequate control rats. The food intake of the dextrin group was the highest under both Zn-deficient and Zn-adequate diets, and that of the fructose group was the lowest. All rats of the dextrin, maltose, sucrose, glucose, and fructose groups with the Zn-deficient status showed a characteristic cyclic variation in food intake and fitted well to a Cosinor curve. The values of the mesor, amplitude, and period of the food intake cycles showed significant differences among the groups. The higher intake of the glucose diet than the fructose diet of rats fed a Zn-deficient diet may be related to the different metabolisms of the carbohydrates used, from the comparison of the quantities consumed in the corresponding carbohydrates of Zn-adequate diets.
\end{abstract}

Key Words zinc deficiency, food intake, body weight change, carbohydrate

Zinc (Zn) deficiency has been claimed to be associated with anorexia, growth retardation, reproductive dysfunction, alopecia, dermatitis, slow wound healing, delayed sexual development and function, and reduced immunocompetence $(1,2)$. Rats fed a Zn-deficient diet show a characteristic cyclic variation in daily food intake, with a frequency of about $3.5 \mathrm{~d}(3-10)$. The cyclic variation of the food intake was analyzed with the four parameters of mesor (the rhythm-adjusted mean), amplitude (maximum and minimum value from the adjusted mean), period (length of one complete cycle), and acrophase (phase of the minimum value), using a personal computer (11-13).

The body-weight of rats fed a Zn-deficient diet also changed $(7,8)$ daily and was well synchronized with the cycle of the food intake (11-13). The values of mesor and, amplitude and the period of the food intake cycle showed a high correlation to the corresponding parameters of body-weight change (12). The values of amplitude for the food-intake cycle showed a positive correlation to their own day-to-day variations and to the correlation value of their own simulated cycles (13). The cyclic variation in the body-weight change of rats fed a Zn-deficient diet occurred similarly in pair-fed control rats (13). There were no significant differences in the mesors of the body-weight change cycles of Zn-deficient rats and pair-fed control rats (13).

The amplitude of the food-intake cycle decreased with increasing Zn-supplementation, while the mesor

* To whom correspondence should be addressed.

E-mail: tamaki@nutr.kobegakuin.ac.jp increased (12-14). The requirement for normalizing the food intake of $\mathrm{Zn}$ from the diet in rats was about $120 \mu \mathrm{g} / \mathrm{d}$, which is $8 \mathrm{mg} / \mathrm{kg}$ diet (13).

Reducing the protein content of the $\mathrm{Zn}$-deficient diet from $20 \%$ to $5 \%$ weakened the cyclic pattern of food intake $(6,8,15)$. The amplitude of the food-intake cycle of rats fed a $\mathrm{Zn}$-deficient diet containing 5\% protein increased twofold by supplementing the diet with Lthreonine (15). However, we could not explain the mechanism of the appearance of the cyclical variation in the food intake cycle of rats fed a Zn-deficient diet. When $\mathrm{Zn}$-deficient rats were allowed to freely select from simultaneously provided carbohydrate-, protein-, and fat-rich diets, carbohydrate intake decreased in parallel with the reduction in total intake (16). Several studies have proposed to link the trace metal $\mathrm{Zn}$ with changes in taste function (17-19).

The present study investigated the food intake of rats fed Zn-deficient and Zn-adequate diets containing dextrin, maltose, sucrose, glucose, or fructose. The qualitative differences among the various carbohydrates were studied in terms of food consumption and favorite food. We analyzed the food-intake cycle of rats fed a Zn-deficient diet, as the parameters of the cycle among the diets containing various carbohydrates as macronutrients.

\section{MATERIALS AND METHODS}

Animals. Male albino rats (Wistar ST strain, weighing 90-100 g) were purchased from Japan SLC Co. Ltd. (Hamamatsu, Japan) and housed in individual screenbottomed cages in a room maintained at $23 \pm 1^{\circ} \mathrm{C}$ and 
Table 1. Compositions of the diets ( $\mathrm{g} / \mathrm{kg})$.

\begin{tabular}{lcc}
\hline \multicolumn{1}{c}{ Ingredients } & Zn-adequate & Zn-deficient \\
\hline Egg Albumin & 200 & 300 \\
Carbohydrate $^{\mathrm{a}}$ & 637 & 637 \\
Corn oil $_{\text {Vitamin mixture }}^{\mathrm{b}}$ & 100 & 100 \\
${\text { Salt mixture }(+\mathrm{Zn})^{\mathrm{c}}}_{\text {Salt mixture }(-\mathrm{Zn})^{\mathrm{d}}}$ & 11.7 & 11.7 \\
Cellulose powder $^{\mathrm{d}}$ & - & - \\
\hline
\end{tabular}

${ }^{a}$ Carbohydrates used were dextrin, maltose, sucrose, glucose, and fructose.

${ }^{\mathrm{b}}$ Vitamins $(\mathrm{mg} / \mathrm{kg}$ of diet): retinyl acetate (2.01), cholecalciferol (0.03), $\alpha$-tocopheryl acetate (58.5), menadione (60.8), thiamin hydrochloride (14.0), riboflavin (46.8), pyridoxine hydrochloride (9.4), cyanocobalamin (0.006), ascorbic acid (351), D-biotin (0.23), folic acid (2.34), calcium pantothenate (58.5), $p$-aminobenzoic acid (58.5), niacin (70.2), and choline chloride $(2,340)$. ${ }^{c}$ Minerals $(+\mathrm{Zn})\left(\mathrm{g} / \mathrm{kg}\right.$ of diet): $\mathrm{CaHPO}_{4} \cdot 2 \mathrm{H}_{2} \mathrm{O}(4.557)$, $\mathrm{KH}_{2} \mathrm{PO}_{4}$ (8.050), $\mathrm{NaH}_{2} \mathrm{PO}_{4}$ (2.927), NaCl (1.459), Calactate (10.983), Fe-citrate (0.995), $\mathrm{MgSO}_{4}$ (2.244), $\mathrm{ZnCO}_{3}(0.034), \mathrm{MnSO}_{4} \cdot 4-6 \mathrm{H}_{2} \mathrm{O}(0.038), \mathrm{CuSO}_{4} \cdot 5 \mathrm{H}_{2} \mathrm{O}$ (0.009), and Kl (0.003).

${ }^{\mathrm{d}}$ Minerals $(-\mathrm{Zn})\left(\mathrm{g} / \mathrm{kg}\right.$ diet): $\mathrm{ZnCO}_{3}$ was omitted from the above mixture.

$50 \%$ humidity with controlled lighting conditions (lights on from 07:00 to 19:00). The animals were fed a commercial stock diet of Oriental MF (Oriental Yeast Ltd., Tokyo, Japan) and given tap water ad libitum for $1 \mathrm{wk}$ before the experiment to allow acclimatization to the new environment. Acclimatized rats showing progressive weight gain were selected and separated into groups of 20 animals. Food intake and body weight were determined daily between 09:00 and 11:00. The rats were given the experimental diet for $4 \mathrm{wk}$, and sacrificed between 09:00 and 11:00 under anesthesia with diethyl ether. All procedures were performed in accordance with the Kobe Gakuin University Guide-lines for the Care and Use of Laboratory Animals.

Diet. The compositions of the Zn-deficient and Znadequate diets are shown in Table 1. The contents of $\mathrm{Zn}$ in the Zn-deficient dextrin, maltose, sucrose, glucose, and fructose diets from the mean values of three separate experiments were $0.95,0.90,1.20,0.75$, and $0.81 \mathrm{mg} / \mathrm{kg}$ diet, respectively.

Chemicals. All chemicals used were of analytical grade and were purchased from Nacalai Tesque (Kyoto, Japan) unless otherwise stated. Animal feed was obtained from Oriental Yeast Ltd. Maltose, sucrose, glucose, and fructose were from Nacalai Tesque. Glucose and fructose used as dietary ingredients were D-form.

$\mathrm{Zn}$ content. A 1-g portion of each test diet was heated for $48-72 \mathrm{~h}$ in a muffle oven at $450^{\circ} \mathrm{C}$. After the sample cooled, $2 \mathrm{~mL}$ of $1 \mathrm{M} \mathrm{HCl}$ was added, and the digestates were heated and diluted with double-distilled deionized water. In the case of serum, it was diluted 1:4 with $0.83 \mathrm{M} \mathrm{HCl}$ and incubated for $30 \mathrm{~min}$ at about $4^{\circ} \mathrm{C}$. After brief centrifugation (3,000 rpm for $10 \mathrm{~min})$, the supernatant was removed and used for $\mathrm{Zn}$ analysis. The stock $\mathrm{Zn}$ and sample solution were analyzed by atomic absorption spectroscopy with a Hitachi Z-5300 Polarized Zeema Atomic Absorption Spectrophotometer (Hitachi Ltd., Tokyo, Japan) at $213.8 \mathrm{~nm}$.

Evaluation of food intake and body-weight changes. Food intake and body-weight change data from $\mathrm{Zn}$-deficient rats were analyzed by the "Cosinor" method (11-13). Food intake $(F)$ and body-weight change $(\Delta B)$ on day $t$ were determined using the following equation:

$F($ or $\Delta B)=M+A \cos (2 \pi t / \tau+\phi)$

where $M, A, \tau$, and $\phi$ represent the mesor (the rhythmadjusted mean), amplitude (maximum and minimum value of the adjusted mean), period (length of one complete cycle), and acrophase (phase of minimum value), respectively. The experimental data were fitted to the above equation by the nonlinear least-squares method (20), and the four parameters, $M, A, \tau$, and $\phi$, were calculated using subroutine analysis (21).

On the other hand, as the data from $\mathrm{Zn}$-adequate rats were not fitted to the above equation, comparisons among groups were evaluated between the mean variation of daily food intake and body-weight change. The variation was calculated for each rat with the standard deviation of the estimate of the day-to-day variation in food intake and body-weight change for $28 \mathrm{~d}$, and the group means presented.

Statistical analysis. Values for food intake and bodyweight change are expressed as means \pm SD. One-way analysis of variance (ANOVA) was used to compare the groups. When a significant difference $(p<0.05)$ was found between groups, the statistical significance of the difference between values was assessed using Duncan's multiple comparison test and considered significant at $p<0.05$. When we made a comparison between groups, the statistical significance of differences between values was assessed by a Student's $t$-test.

\section{RESULTS}

Effect of carbohydrates on the food intake and body-weight change of rats fed either Zn-adequate or Zn-deficient diet

The carbohydrates used as macronutrients were dextrin, maltose, sucrose, glucose and fructose, and the food intake and body weight were estimated daily. The mean values and the day-to-day variations (variability) in food intake and body-weight change for $4 \mathrm{wk}$ are summarized in Tables 2 and 3. The food intake and body-weight change of $\mathrm{Zn}$-deficient rats were significantly less than those of the $\mathrm{Zn}$-adequate control rats throughout the 4-wk study. However, the values of variability from mean food intake and body weight change in each group of Zn-deficient rats increased by about 2fold compared to those in the Zn-adequate control groups (Tables 2 and 3). Among the Zn-adequate control groups throughout the $4 \mathrm{wk}$, the dextrin group showed the greatest appetite, while the fructose group showed the smallest appetite. The differences in food intake of Zn-deficient rats among carbohydrates follow those of Zn-adequate rats. In rats fed the $\mathrm{Zn}$-adequate control diet, the dextrin group showed the most effec- 
Table 2. Effect of carbohydrates on the food intake of rats fed either a Zn-adequate or Zn-deficient diet.

\begin{tabular}{|c|c|c|c|c|}
\hline & \multicolumn{2}{|c|}{ Zn-adequate } & \multicolumn{2}{|c|}{ Zn-deficient } \\
\hline & $\begin{array}{l}\text { Food intake } \\
\qquad(\mathrm{g} / \mathrm{d})\end{array}$ & $\begin{array}{c}\text { Variation in } \\
\text { food intake }(\mathrm{g} / \mathrm{d})\end{array}$ & $\begin{array}{l}\text { Food intake } \\
\qquad(\mathrm{g} / \mathrm{d})\end{array}$ & $\begin{array}{c}\text { Variation in } \\
\text { food intake }(\mathrm{g} / \mathrm{d})\end{array}$ \\
\hline Dextrin & $15.6 \pm 1.7^{\mathrm{c}}$ & $2.2 \pm 0.5^{\mathrm{c}}$ & $10.5 \pm 1.5^{* *, \mathrm{~d}}$ & $4.7 \pm 0.7^{* *, \mathrm{c}}$ \\
\hline Maltose & $14.1 \pm 1.4^{\mathrm{b}}$ & $2.1 \pm 0.4^{\mathrm{b}}$ & $9.4 \pm 0.6^{* *, \mathrm{c}}$ & $4.1 \pm 0.6^{* *, b}$ \\
\hline Sucrose & $13.7 \pm 1.1^{\mathrm{b}}$ & $2.0 \pm 0.5^{b}$ & $8.4 \pm 0.7^{* *, a, b}$ & $3.9 \pm 0.4^{* *, b}$ \\
\hline Glucose & $13.7 \pm 1.0^{\mathrm{b}}$ & $1.7 \pm 0.4^{\mathrm{a}}$ & $8.5 \pm 0.9^{* *, b}$ & $3.5 \pm 0.4^{* *, \mathrm{a}}$ \\
\hline Fructose & $12.7 \pm 0.4^{\mathrm{a}}$ & $2.2 \pm 0.4^{c}$ & $7.9 \pm 1.0^{* *, a}$ & $3.4 \pm 0.7^{* *, \mathrm{a}}$ \\
\hline
\end{tabular}

The values of food intake were from 20 rats for each group. The variations in food intake are given as standard deviations from the mean of $28 \mathrm{~d}$ of data for the groups. The values are shown as means with standard deviations. Values in each column not sharing a common superscript letter are significantly different $(p<0.05)$.

** Mean value was significantly different from that of the control group, $p<0.01$.

Table 3. Effect of carbohydrates on the body-weight change of rats fed either a Zn-adequate or Zn-deficient diet.

\begin{tabular}{|c|c|c|c|c|}
\hline & \multicolumn{2}{|c|}{ Zn-adequate } & \multicolumn{2}{|c|}{ Zn-deficient } \\
\hline & $\begin{array}{l}\text { Weight change } \\
\qquad(\mathrm{g} / \mathrm{d})\end{array}$ & $\begin{array}{l}\text { Variation in } \\
\text { weight change }(\mathrm{g} / \mathrm{d})\end{array}$ & $\begin{array}{l}\text { Weight change } \\
\qquad(\mathrm{g} / \mathrm{d})\end{array}$ & $\begin{array}{c}\text { Variation in } \\
\text { weight change }(\mathrm{g} / \mathrm{d})\end{array}$ \\
\hline Dextrin & $5.1 \pm 0.6^{c}$ & $3.6 \pm 1.2^{\mathrm{c}}$ & $2.4 \pm 1.0^{* *, \mathrm{c}}$ & $8.1 \pm 1.6^{* *, \mathrm{c}}$ \\
\hline Maltose & $4.0 \pm 1.1^{\mathrm{b}}$ & $2.7 \pm 0.4^{\mathrm{a}}$ & $1.0 \pm 0.3^{* *, b}$ & $6.2 \pm 0.8^{* *, \mathrm{~b}}$ \\
\hline Sucrose & $4.0 \pm 0.7^{b}$ & $3.0 \pm 0.7^{\mathrm{a}, \mathrm{b}}$ & $0.5 \pm 0.5^{* *, \mathrm{a}}$ & $6.4 \pm 0.8^{* *, b}$ \\
\hline Glucose & $3.7 \pm 0.8^{b}$ & $2.5 \pm 0.6^{\mathrm{a}}$ & $0.9 \pm 0.5^{* *, a, b}$ & $5.4 \pm 0.7^{* *, \mathrm{a}}$ \\
\hline Fructose & $3.2 \pm 0.4^{\mathrm{a}}$ & $3.3 \pm 0.7^{b, c}$ & $0.5 \pm 0.5^{* *, \mathrm{a}}$ & $5.2 \pm 0.7^{* *, \mathrm{a}}$ \\
\hline
\end{tabular}

The values of body-weight change were from 20 rats for each group. The variations in food intake are given as standard deviations from the mean of $28 \mathrm{~d}$ of data for the groups. The values are shown as means with standard deviations. Values in each column not sharing a common superscript letter are significantly different $(p<0.05)$.

** Mean value was significantly different from that of the control group, $p<0.01$.

tive growth and the fructose group the lowest (Table 3). The body-weight change of rats fed the Zn-deficient diet was retarded as compared to those of the corresponding carbohydrate groups fed the $\mathrm{Zn}$-adequate diet. The variation in food intake and body-weight change of rats fed the Zn-deficient diet containing each carbohydrate increased about 2- to 4-fold more and followed a cyclic variation. Dextrin was the most favorable for the growth of rats fed either the $\mathrm{Zn}$-adequate diet or the $\mathrm{Zn}$ deficient diet. Fructose and sucrose showed a lower contribution to growth than maltose for $\mathrm{Zn}$-deficient rats.

In rats fed the $\mathrm{Zn}$-adequate diet, the food intake of all groups increased throughout the $4 \mathrm{wk}$, but that in the groups fed the Zn-deficient diet was not affected by age except for the maltose group (data not shown). The significant difference of variation in the food intake of rats fed the Zn-deficient diet and the control rats fed the Znadequate diet appeared in the 1 st week and the values of variation in food intake increased with age except for the dextrin-group (data not shown).

The $\mathrm{Zn}$ level in the serum showed a significant decrease in the Zn-deficient diet groups (Fig. 1). However, none of the carbohydrates used in the Zn-deficient diets showed any significant differences among the groups.

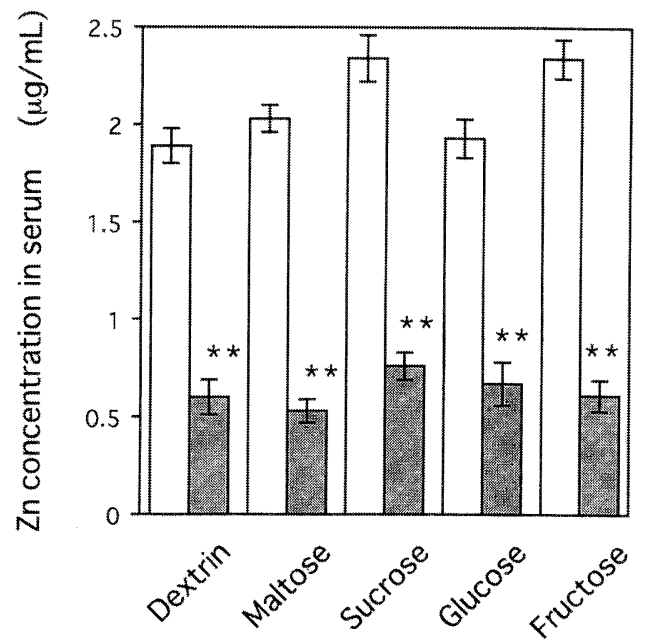

Fig. 1. Zn concentration in serum. Carbohydrates administered to rats fed $\mathrm{Zn}$-adequate (white column) and Zn-deficient (dotted column) diets. Values are means, with their standard errors indicated by the vertical bars. ${ }^{* *} p<0.01$ compared with the corresponding $\mathrm{Zn}$ adequate control. 
Table 4. Effect of dietary carbohydrates on the parameters of food intake and body-weight change cycles of rats fed the Zndeficient diet.

\begin{tabular}{lcccc}
\hline & $\begin{array}{c}M \\
(\mathrm{~g} / \mathrm{d})\end{array}$ & $\begin{array}{c}A \\
(\mathrm{~g} / \mathrm{d})\end{array}$ & $\begin{array}{c}\tau \\
(\mathrm{d})\end{array}$ & $\begin{array}{c}\phi \\
\text { (radian) }\end{array}$ \\
\hline $\begin{array}{l}\text { Food intake } \\
\text { Dextrin }\end{array}$ & & & \\
Maltose & $10.4 \pm 1.5^{\mathrm{c}}$ & $5.3 \pm 1.1^{\mathrm{c}}$ & $3.5 \pm 0.3^{\mathrm{a}}$ & $-0.4 \pm 2.13$ \\
Sucrose & $9.4 \pm 0.5^{\mathrm{b}}$ & $4.5 \pm 0.9^{\mathrm{a}}$ & $3.8 \pm 0.2^{\mathrm{b}}$ & $0.1 \pm 2.2$ \\
Glucose & $8.3 \pm 0.7^{\mathrm{a}}$ & $4.4 \pm 0.7^{\mathrm{b}}$ & $3.8 \pm 0.2^{\mathrm{b}}$ & $0.8 \pm 2.5$ \\
Fructose & $8.5 \pm 0.9^{\mathrm{a}}$ & $3.6 \pm 0.8^{\mathrm{a}}$ & $3.7 \pm 0.2^{\mathrm{b}}$ & $0.4 \pm 2.4$ \\
Body-weight change & $7.9 \pm 1.0^{\mathrm{a}}$ & $4.0 \pm 0.7^{\mathrm{a}, \mathrm{b}}$ & $4.0 \pm 0.3^{\mathrm{c}}$ & $-0.1 \pm 2.2$ \\
Dextrin & & & & $-0.4 \pm 2.2$ \\
Maltose & $2.3 \pm 1.0^{\mathrm{c}}$ & $8.7 \pm 2.2^{\mathrm{c}}$ & $3.5 \pm 0.4^{\mathrm{a}}$ & $0.8 \pm 2.0$ \\
Sucrose & $1.0 \pm 0.3^{\mathrm{b}}$ & $6.6 \pm 1.5^{\mathrm{b}}$ & $3.7 \pm 0.2^{\mathrm{b}}$ & $1.6 \pm 2.0$ \\
Glucose & $0.5 \pm 0.6^{\mathrm{a}}$ & $6.8 \pm 1.4^{\mathrm{b}}$ & $3.7 \pm 0.2^{\mathrm{b}}$ & $0.2 \pm 2.4$ \\
Fructose & $0.8 \pm 0.5^{\mathrm{a}, \mathrm{b}}$ & $5.6 \pm 1.3^{\mathrm{a}}$ & $3.6 \pm 0.2^{\mathrm{a}, \mathrm{b}}$ & $1.2 \pm 1.8$ \\
\hline
\end{tabular}

Each rat was fed the experimental diet for $28 \mathrm{~d}$ under the conditions described in Materials and Methods. Food intake $(F)$ or body-weight change $(\Delta B)$ in the previous 24 -h period at day $t: F$ (or $\Delta B)=M+A \cos (2 \pi t / \tau \pm \phi)$. Each value is the mean $\pm S D$. Values in each column not sharing a common superscript letter are significantly different $(p<0.05)$.

Comparison of cyclical food intake cycles of rats fed Zn-deficient diets containing dextrin, maltose, sucrose, glucose, or fructose

When dextrin, maltose, sucrose, glucose, or fructose were used as a source of carbohydrates in the Zn-deficient diet, rats fed all kinds of carbohydrates showed a characteristic cyclic variations in food intake. However, the food intake of rats fed the Zn-adequate diet did not show any signs of cyclic variation. The body-weight changes of the Zn-deficient rats also showed cyclic variations and were well synchronized with food intake.

The findings for food intake and body-weight change in the previous 24-h period for the Zn-deficient rats were analyzed. We evaluated the parameters of both cycles of rats fed the Zn-deficient diet containing dextrin, maltose, sucrose, glucose, and fructose as shown in Table 4. We found significant differences in the parameters among the groups. The mesor of the food intake and body-weight cycles was highest in the dextrin group, followed by the maltose group, and was lowest in the sucrose, glucose, and fructose groups. The amplitude of the food intake and body-weight change cycles was highest in the dextrin group, followed by the disaccharide groups. The periods for both groups were expanded in the fructose group. The acrophase of both cycles showed high individual variation and there were no significant differences among the groups, based on reflections of variations in the rate of initial onset of the deficiency $(11,12)$.

\section{DISCUSSION}

The findings reported here provide characteristic evidence that qualitative differences in dietary carbohydrates in rats could be found in the food intake and body-weight change between groups fed Zn-deficient diet and $\mathrm{Zn}$-adequate diets. Here, we found that, in the fructose group, the food intake of rats fed the Zn-adequate diet was lower than that of the glucose group as reported previously $(22,23)$. In the case of rats fed the $\mathrm{Zn}$-deficient diet, the food intake in the fructose group was also lower than that in the glucose group (Table 2). The body-weight changes in the fructose group of both the $\mathrm{Zn}$-adequate control rats and the Zn-deficient rats showed significant differences compared with those of the glucose group. The molecular formula of fructose is the same as glucose. The osmotic pressure in digestive tracts after feeding the diets may not have shown any significant difference between the fructose- and glucosediet groups. Fructose can be phosphorylated by either hexokinase (EC 2.7.1.1) or ketohexokinase (EC 2.7.1.3) and is then catabolized via the glycolitic pathway. Comparisons of $\mathrm{Km}$ values and Vmax of hexokinase and ketohexokinase suggested that ketohexsokinase has a more important role for the catabolism of fructose (24). The different catabolic pathway between glucose and fructose may affect the food intake of rats under Zn-deficient conditions in addition to $\mathrm{Zn}$-adequate conditions.

The daily food intake and body-weight change of the dextrin group of rats under Zn-deficient conditions as well as those under $\mathrm{Zn}$-adequate conditions showed higher values than those of the maltose-, sucrose-, glucose-, and fructose-groups. These results suggest that dextrin may weaken the osmotic stress in the small intestine more than disaccharides and monosaccharides under both $\mathrm{Zn}$-deficient and $\mathrm{Zn}$-adequate conditions, and that the dextrin diet may be favorable to be an energy source.

All values on the day-to-day variation of food intake of rats fed dextrin-, maltose-, sucrose-, glucose-, and fructose-Zn-deficient diets were higher than the corresponding variation in the $\mathrm{Zn}$-adequate carbohydrate diet groups, and larger variations followed the appearance of the cyclic phenomena of food intake and bodyweight change. Cyclical food intake appeared not to be caused by excess food consumption, but rather by a periodic reduction in the rat's appetite (13). When the 
Zn-deficient rats were fed a glucose or fructose diet at the top of the food intake cycle, they ate these monosaccharides in smaller amounts than the disaccharides of maltose and sucrose.

The periods of food intake and body-weight change cycles of the rats fed the $\mathrm{Zn}$-deficient fructose diet were expanded. Harper et al. (25), Cohen and Teitelbaum (26), and Chalvarjian and Stephens (27) suggested that the livers of animals fed a diet containing either sucrose or fructose contain more lipids than those of animals fed a diet containing starch, dextrin or glucose. Aoyama et al. $(28,29)$ proposed that feeding a protein-repletion diet containing fructose to protein-depleted rats results in marked lipid accumulation in the liver. Fructose degrades to dihydroxy acetone phosphate and D-glyceroaldehyde via D-fructose 1-phosphate, and is further metabolized through glycolysis. Therefore, the expansion of the food-intake cycle period may depend on the glycolytic pathway of fructose. A retardation of the fructose diet was found under Zn-deficient conditions as well as Zn-adequate conditions.

The $\mathrm{NaCl}$ preference in rats fed the $\mathrm{Zn}$-deficient diet was significantly greater than in pair-fed controls or in rats fed the Zn-supplemented diet ad libitum (30). Mc Connell and Henkin (30) proposed that the $\mathrm{NaCl}$ preference was related to the amount of dextrin in the diet. The carbohydrate preference in rats fed $\mathrm{Zn}$-deficient diets is not well establised. In the present study, we found that the food intake of the fructose-supplemented diet in rats fed the Zn-deficient diet was significantly less than that of the glucose, maltose, or sucrose diet. However, the daily food intake of the fructose diet in rats fed the $\mathrm{Zn}$-adequate control diets was also significantly less than that of the other saccharide diets. These results suggest that the lower intake of the fructose-diet rats fed the $\mathrm{Zn}$-deficient diet may not depend on retardation of appetite and altered taste perception. The plasma $\mathrm{Zn}$ concentration in rats falls by approximately $40 \%$ after $1 \mathrm{~d}$ on a Zn-deficient diet (31). Therefore, the decreased level of plasma $\mathrm{Zn}$ in rats fed the $\mathrm{Zn}$-deficient diet may significantly increase the variability of food intake at an early stage and show signs of periodical retardation of food intake.

\section{REFERENCES}

1) Forbes RM. 1984. Use of laboratory animals to define physiological functions and bioavailability of zinc. Federation Proc 43: 2835-2839.

2) Hambidge KM, Casey CE, Krebs NE. 1986. Zinc. In: Trace Elements in Human and Animal Nutrition II (Mertz W, ed), p 1-37. Academic Press, Olando, FL.

3) Mills CF, Quarterman J, Chesters JK, Williams RB, Dalgarno AG. 1969. Metabolic role of zinc. Am J Clin Nutr 22: 1240-1249.

4) Chesters JK, Quarterman J. 1970. Effects of zinc deficiency on food intake and feeding patterns of rats. $\mathrm{Br} J$ Nutr 24: 1061-1069.

5) Williams RB. 1972. Intestinal alkaline phosphatase and inorganic pyrophosphatase activities in the zinc-deficient rat. Br J Nutr 27: 121-130.

6) Chesters JK, Will M. 1973. Some factors controlling food intake by zinc-deficient rats. Br J Nutr 30: 555566.

7) Wallwork JC, Fosmire GJ, Sandstead HH. 1981. Effect of zinc deficiency on appetite and plasma amino acid concentrations in the rat. Br J Nutr 45: 127-136.

8) Giugliano R, Millward DJ. 1984. Growth and zinc homeostasis in the severely Zn-deficient rat. Br J Nutr 52: $545-560$.

9) Kramer TR, Briske-Anderson M, Johnson SB, Holman RT. 1984. Influence of reduced food intake on polyunsaturated fatty acid metabolism in zinc-deficient rats. $J$ Nutr 1 14: 1224-1230.

10) Quinn PB, Cremin FM, O'sullivan VR, Hewedi FM, Bond RJ. 1990. The influence of dietary folate deficient rats. Br J. Nutr 64: 233-243.

11) Tamaki N, Fujimoto-Sakata S, Kikugawa M, Kaneko M, Onosaka S, Takagi T. 1995. Analysis of cyclic feed intake in rats fed on a zinc-deficient diet and the level of dihydropyrimildinase (EC 3.5.2.2). Br J Nutr 73: 711-722.

12) Aiba K, Kimura M, Sakata S, Matsuda K, Kaneko M, Onosaka S, Yamaoka Y, Tamaki N. 1997. Cosinor analysis of feed intake cycle of rats fed a zinc-deficient diet and the effect of zinc supplementation. J Nutr Sci Vitaminol 43: 327-343.

13) Yamasaki K, Kaneko M, Matsuda K, Fujimoto Sakata S, Tamaki N. 1999. The correlation between feed-intake cycle and nutritional zinc-deficient status in rats. J Nutr Sci Vitaminol 45: 621-632.

14) Williams RB, Mills CF. 1970 . The experimental production of zinc deficiency in the rats. Br J Nutr 24: 989 1003.

15) Yamasaki K, Ohyama T, Horikawa Y, Matsuda K, Fujimoto Sakata S, Tamaki N. 2002. L-Threonine supplementation increases the amplitude of the feed intake cycle of rats fed a low-protein zinc-deficient diet. J Nutr Sci Vitaminol 48: 230-237.

16) Rains TM, Shay NF. 1995. Zinc status specifically changes preferences for carbohydrate and protein in rats selecting from separate carbohydrate-, protein-, and fat-containing diets. J Nutr 125: 2874-2879.

17) Henkin RI, Schechter PJ, Raff MS, Bronzert DA, Friedewald WT. 1974. Zinc and taste acuity: a clinical study including a laser microprobe analysis of the gustatory receptor area. In: Clinical Application of Zinc Metabolism (Prories WJ, Strain WH, Hsu JM, Woosley RL, eds), p 204-228. Charles C Thomas, Publisher, Springfield, IL.

18) Catalanotto FA. 1978. The trace metal zinc and taste. Am J Clin Nutr 31: 1098-1103.

19) Wright AL, King JC, Baer MT, Citron LJ. 1981. Experimental zinc depletion and altered taste perception for $\mathrm{NaCl}$ in young adult males. Am J Clin Nutr 34: 848852.

20) Marquardt DW. 1963. An algorithm for least-squared estimation of non linear parameters. J Soc Indust Appl Math 11: 431-441.

21) Yamaoka K, Tanigawara Y, Nakagawa T, Ueno T. 1981. A pharmacokinetic analysis program (MULTI) for microcomputer. J Phrmacobio-Dyn 4: 879-885.

22) Hirasawa F, Shimogaki R, Tokita A, Fukagawa S, Koike G, Yoshikawa H. 1972. The effect of sucrose, glucose and fructose feeding on the lipid content of liver and serum of albino rats. Nippon Eiyo Shokuryo Gakkaishi (J Jpn Soc Nutr Food Sci) 25: 328-332 (in Japanese).

23) Kim SH, Keen CL. 1999. Influence of dietary carbohy- 
drate on zinc-deficiency-induced changes in oxidative defense mechanisms and tissue oxidative damage in rats. Biol Trace Element Res 70: 81-96.

24) Zakin D, Herman RH. 1968. Fructose metabolism II. Regulatory control to the triose leve. Am J Clin Nutr $\mathbf{2 1}$ : 315-319.

25) Harper AE, Monson WJ, Arata DA, Beaton DA, Elvehiem CA. 1953. Influence of various carbohydrates on the utilization of low protein ratios by the white rats. II. Composition of several proteins and carbohydrates. Growth and liver fat. J Nutr 51: 523-537.

26) Cohen AM, Teitelbaum A. 1964. Effect of dietary sucrose and starch on oral glucose tolerance and insulin-like activity. Am J Physiol 206: 105-108.

27) Chalvarjian A, Stephens S. 1970. Lipotropic effect of dextrin versus sucrose in choline-deficient diet. J Nutr 100: $397-403$.

28) Aoyama Y, Ashida K. 1973. Effect of various carbohydrates in a repletion diet after protein depletion on liver lipid content of rats. J Nutr 103: 225-230.

29) Aoyama Y, Izumichi T, Sakakibara H, Yohida A, Ashida K. 1975. Effect of glucose and fructose in the proteinrepletion diet fed after protein-depletion on the lipid metabolism in rats. Nutr Rep Int 12: 163-173.

30) Mc Connell SD, Henkin RI. 1974. Altered preference for sodium chloride, anorexia, and changes in plasma and urinary zinc in rats fed a zinc-deficient diet. J Nutr 104: 1108-1114.

31) Wilkins PJ, Grey PC, Deosti IE. 1972. Plasma zinc as an indicator of zinc status in rats. Br J Nutr 27: 113-120. 